\title{
Capable but insane
}

\section{John Launer}

For anyone who is interested in personal narratives of illness, it is hard to find one that is more remarkable than Memoirs of my nervous illness by Daniel Paul Schreber. Schreber was a judge in Germany at the end of the nineteenth century. He suffered from what we would now call paranoid schizophrenia. At the age of 51 he was admitted to a psychiatric asylum-first voluntarily, then under a court order-for 9 years. Towards the end of this period, he believed himself to be recovering, but his doctors did not take the same view. Although his behaviour was acceptable at this stage, it was clear to them that his ideas were still bizarre. He thus began a prolonged legal battle for his release. To support his case, he wrote a book-length account of his experiences and beliefs, which he subsequently expanded and then published. In the last few years, this has been reissued with an introduction by the writer Rosemary Dinnage, together with the medical reports that his psychiatrist submitted to the court and the final judgement releasing him to the outside world. ${ }^{1}$ It makes fascinating reading, not just for psychiatrists but for any doctor who may deal with disturbed people at times.

\section{PATENTLY MAD}

The opening pages set the tone for the book. They are articulate, compelling, coherentand patently mad. Even though he felt he had recovered, Schreber still believed he had come under the influence of rays from the director of his previous asylum, Professor Flechsig. These rays were in turn a manifestation of rays from God, intended not only to make him suffer but to redeem the world and restore it to a state of Blessedness. As part of this redemptive process, he sometimes experienced his penis as invaginating in order to transform into a womb and ovaries, with the aim of allowing him to repopulate the world. Within what Dinnage describes as "the complicated, mythic universe that Schreber in his captivity created", there are not only rays and miracles, but upper and lower gods, souls and soul murder, voices of nerve language, and struggles against the "Order of the World". There are speculations on the nature of God and of the different religions. Schreber describes how his mind was possessed or

Correspondence to: Dr John Launer, London Deanery, Stewart House, London WC1B 5DN, UK; jlauner@ londondeanery.ac.uk populated at various times by Benedictine monks, Jesuits, the Eternal Jew and a Mongolian prince. And so on and so forth.

Schreber gives some very precise and persuasive accounts of some common mental phenomena including aural hallucinations and intrusive thoughts. For example, at one point he describes how external voices may repeat certain phrases to him over and over again, but with the same word missing each time so that he feels compelled to complete the phrase by saying it to himself. As Dinnage points out, we are given insights into the development and nature of a healthy mind, through being granted such a detailed and privileged description of one that has become "forsaken". There is some guidance, too, about what may help when people are in such desperate states of mind. This includes music, which at times seemed to Schreber to provide an alternative form of order, logic and language that was able to suppress the cacophony that generally persecuted him.

\section{FOOD FOR THOUGHT}

Schreber takes over 250 pages to explain his entire delusional system-as we would regard it-although he makes it clear he can barely begin to give an account of his revelations in so short a volume. Ultimately, he claims, these cannot really be expressed in words but are only available to intuition. His memoir certainly offers food for thought philosophically. He addresses some of the key questions that have taxed thinkers across the ages, including the nature of reality and how we know what truly exists. He does so in a manner that is clearly learned, with copious references including literary and scientific ones. There are moments when his manner of thinking appears to recall the kind of fringe religious cults that have always existed across the ages, and may even seem privy to hidden truths about the world. It isn't hard to imagine reading about his beliefs with curiosity rather than diagnosis in mind if, for example, they were reported as part of an anthropological account of a remote tribe.

The memoir has been subjected to many commentaries and judgements since it was first published. The most notable of these was from Freud, who believed that Schreber's disturbance arose from repressed homosexuality. Later, the liberal psychiatrist Thomas Szasz drew attention to how Schreber's incarceration and treatment may itself have amplified his disturbance. More recently, the focus of speculation has often been on Schreber's family and particularly on his father, Moritz, a noted authority of his time on child-rearing. Among the published guidance given by Schreber senior was the advice that children should have icy baths daily from the age of 3 months, be taught to obey their parents unquestioningly in all circumstances, and be strapped to special boards (marketed as the Schreber Geradehalte) if they slouched. His system was widely influential in Germany, and arguably contributed to the mind set that later made Nazism possible.

\section{ENLIGHTENED DECISION}

All of these hypotheses are interesting, although personally I find little direct evidence for any of them in the text or court reports. What I find more notable is the scrupulous attitude of his psychiatrist, Dr Guido Weber, in his three written submissions to the court. In a careful, literate style, Weber emphasises more than once that his role is to describe and not to judge. He analyses the nature of Schreber's disordered thoughts, but at the same time points out that such highly organised delusions can coexist with normal social function. He even draws the sympathetic analogy of a gifted scientist who might hold passionate religious beliefs without them interfering with his scientific work, and with his colleagues entirely unaware of them. Even though he seems to have been opposed to Schreber's release, it is likely that Weber's even-handedness played a major part in leading the court to their surprisingly enlightened decision on appeal: "The Court is in no doubt that the appellant is insane... [However] the Court of Appeal has arrived at the conviction that the plaintiff is capable of dealing with the demands of life in all its spheres".

Schreber was a free man again, but his story does not have a happy ending. When his wife, Sabine, suffered a stroke, he had another breakdown, returned to the asylum, and stayed there until his death at the age of 69 . Yet his memoir remains a model among illness narratives, and an example of how much personal accounts can help us deepen our understanding of what patients experience.

\section{Competing interests: None.}

Postgrad Med J 2009;85:112

doi:10.1136/pgmj.2009.079129

\section{REFERENCE}

1. Schreber DP. Memoirs of my nervous illness. New York: New York Review Books, 2000. 